\title{
Development and Validation of Scar Marker for Stem Rust Resistance Gene Sr26 in Wheat (Triticum aestivum L.)
}

Ruchi Rai ${ }^{*}$, Das BK and Bhagwat SG

Nuclear Agriculture and Biotechnology Division; Bhabha Atomic Research Centre, India

*Corresponding author: Ruchi Rai, Nuclear Agriculture and Biotechnology Division; Bhabha Atomic Research Centre, Mumbai-400085, India, Tel: 0034628784540; Fax: 628784540; E-mail: ruchivrai@yahoo.co.in

Received date: April 24, 2017; Accepted date: May 16, 2017; Published date: May 24, 2017

Copyright: ( 2017 Rai R, et al. This is an open-access article distributed under the terms of the Creative Commons Attribution License, which permits unrestricted use, distribution and reproduction in any medium, provided the original author and source are credited.

\begin{abstract}
The stem rust resistance gene Sr26 imparts resistance to all the virulent pathotypes of stem rust (Puccinia graminis f. sp. tritici) including a new race of pathogen named TTKSK (syn.Ug99). Wheat genotypes including noncarrier Kalyan Sona $(-S r 26)$ and carrier Kite $(+S r 26)$ of the Sr26 gene were analysed using polymerase chain reactions and a RAPD marker OPAE07620 was found to link with the desired trait. Linkage between the marker OPAE07620 and rust resistance phenotype was confirmed by analyzing F2 population obtained from a cross between a resistant and susceptible genotype. The Random Amplified Polymorphic DNA (RAPD) marker was converted into sequence characterized amplified region (SCAR) marker SCOPAE07620. The marker was validated in another segregating population and 45 wheat genotypes including carrier and non-carriers of Sr26 gene. The marker developed in this study can be used for pyramiding of the Sr26 gene with other major resistance genes that are effective against the TTKSK lineage (Ug99) which will help in attaining durable resistance against a disease that poses a serious threat to global wheat production.
\end{abstract}

Keywords: Triticum aestivum L.; Stem rust resistance; Sr26; SCAR marker; MAS

\section{Introduction}

Wheat is the most widely grown cereal crop globally after maize and rice which provides $21 \%$ of food calories and $20 \%$ of the protein for more than 4.5 billion people in 94 developing countries [1]. The rust diseases of wheat, i.e., leaf rust, stripe rust, and stem rust are major biotic constraints in the world [2]. Stem rust, caused by Puccinia graminis f. sp. tritici, is one of the most destructive diseases of wheat. Stem rust epidemics have resulted in as much as $50 \%$ yield losses in recent years [3], A new race of the pathogen named TTKSK (syn. Ug99) detected in Uganda in 1999 [4] and its variants are virulent to many designated and undesignated stem rust resistance genes, losses due to Ug99 can be as high as $90 \%$ [3]. An effective method to combat emergence and spread of Ug99 races would be to stack several broadly effective resistance genes into new adapted variety using marker assisted breeding (MAB). Success of gene pyramiding depends on the availability of molecular markers tightly linked to resistance genes Sr22, Sr26, Sr25 and Sr35 that confer resistance to Ug99 and other virulent races [5] and breeding efforts to pyramid these genes are already underway.

Sr26 is one the few known major resistance genes effective against the Sr31-virulent race Ug99 (TTKSK). Sr26 was transferred from Knott's Agropyron elongatum Thatcher stock [6] into Australian cultivars such as Eagle, Kite and Jabiru. Translocation lines with shorter Agropyron elongatum segments were developed that have been observed not to exhibit the reported $9 \%$ yield penalty associated with the Sr26 segment. The effectiveness of this gene against the TTKS family of races, its low frequency among Indian cultivars and the availability of donor lines with shortened alien segment makes Sr26 ideal for use in MAB. Several DNA markers linked to various stem rust resistance genes in wheat have been identified and developed. The genes include Sr2 [7,8], Sr1RAmigo [9], Sr6 [10], Sr9a [11], Sr24 [9,12], Sr25 [13], Sr26 [12,13], Sr31[14], Sr35 [15], Sr36 [16], Sr38 [17], Sr39 [18], Sr40 [19]. These molecular markers help in deployment of several resistance genes in single cultivar which is otherwise a timeconsuming method if done using rust reaction in field condition. Molecular markers might simulate selection gain [20] because they can be assessed in high-throughput techniques at a very early growth stage with high heritability and they are relatively cheap [21]. They can be used to characterize parental material better, thereby improving the efficiency and effectiveness of parental selection for crossing and to track genes in segregating progenies through the selection process. The marker reported in this study is based on co-segregation study for stem rust resistance conferred by $\operatorname{Sr} 26$ and hence the results and procedures may be applied for use in MAS. It will assist in the stacking of resistance gene with other broadly effective resistance genes in order to develop wheat lines with potentially stable and durable stem rust resistance.

\section{Materials and Methods}

\section{Plant materials}

A total of 45 wheat genotypes (seeds were procured from IARI, New Delhi; DWR, Karnal and NBPGR, IIWBR Regional Station (previously DWR Regional Station), Flowerdale, Shimla) were used for validation of marker in this study (Table 1) of which 12 were carriers of Sr26 and remaining 33 were non-carriers of Sr26. A segregating F2 population was developed from cross between Kalyan Sona (susceptible) and Kite (resistant; + Sr26). Another cross was made between Kalyan Sona and Takari (+Sr26) for validation of the marker. 
Citation: Rai R, Das BK, Bhagwat SG (2017) Development and Validation of Scar Marker for Stem Rust Resistance Gene Sr26 in Wheat (Triticum aestivum L.). Biol Syst Open Access 6: 181. doi:10.4172/2329-6577.1000181

Page 2 of 4

\begin{tabular}{|c|c|c|c|c|c|c|c|}
\hline S. No. & $\begin{array}{l}\text { Varieties/ } \\
\text { Genotypes }\end{array}$ & $\begin{array}{l}\text { Sr26 } \\
\text { status }\end{array}$ & $\begin{array}{l}\text { SCAR } \\
\text { status }\end{array}$ & S. No. & $\begin{array}{l}\text { Varieties/ } \\
\text { Genotype } \\
\text { s }\end{array}$ & $\begin{array}{l}\text { Sr26 } \\
\text { status }\end{array}$ & $\begin{array}{l}\text { SCAR } \\
\text { status }\end{array}$ \\
\hline 1 & Takari & + & + & 24 & HW-2001 & - & - \\
\hline 2 & Flinder & + & + & 25 & HW-2003 & - & - \\
\hline 3 & Jabiru & + & + & 26 & HW-2004 & - & - \\
\hline 4 & Harrier & + & + & 27 & FLW-2 & - & - \\
\hline 5 & Apollo & + & + & 28 & A-9-30-1 & - & - \\
\hline 6 & HW2002 & + & + & 29 & NW-1012 & - & - \\
\hline 7 & HW2023 & + & + & 30 & PBW-373 & - & - \\
\hline 8 & HW2027 & + & + & 31 & UP-2338 & - & - \\
\hline 9 & HW2090 & + & + & 32 & HW-1085 & - & - \\
\hline 10 & HW2094 & + & + & 33 & HD-2687 & - & - \\
\hline 11 & HW2096 & + & + & 34 & HD-2189 & - & - \\
\hline 12 & HW2099 & + & + & 35 & HS-240 & - & - \\
\hline 13 & NIAW-301 & - & - & 36 & Marquis & - & - \\
\hline 14 & PBW-435 & - & - & 37 & Reliance & - & - \\
\hline 15 & Lok-45 & - & - & 38 & Kanchan & - & - \\
\hline 16 & PBN-51 & - & - & 39 & Vidisha & - & - \\
\hline 17 & Hindi-62 & - & - & 40 & Vaishali & - & - \\
\hline 18 & NP-846 & - & - & 41 & Kota & - & - \\
\hline 19 & Sonora-64 & - & - & 42 & Kavkaz & - & - \\
\hline 20 & HI-385 & - & - & 43 & W3531 & - & - \\
\hline 21 & $\begin{array}{l}\text { Kharchia-6 } \\
5\end{array}$ & - & - & 44 & RL-6087 & - & - \\
\hline 22 & A-206 & - & - & 45 & PBW-343 & - & - \\
\hline 23 & $\begin{array}{l}\text { Bijaga } \\
\text { Yellow }\end{array}$ & - & - & & & & \\
\hline
\end{tabular}

to Eswaran et al. [23]. RAPD analysis was carried out using 100 random decamer primers procured from Operon Technologies Inc., Alamaenda, CA, USA (kits A, B, C, D, E). The PCR reactions were performed in $25 \mu \mathrm{l}$ volume, containing $10 \mathrm{~mm}$ Tris- $\mathrm{HCl}$ ( $\mathrm{pH}$ 9.0), 2.0 $\mathrm{mm} \mathrm{MgCl}_{2}, 50 \mathrm{~mm} \mathrm{KCl}, 200 \mu \mathrm{m}$ of each dNTP, $25 \mathrm{pmol}$ of primer, 1.0 Unit of Taq DNA polymerase (Bangalore Genei Pvt. India Ltd.) and 50 ng of template DNA. The PCR was carried out in Mastercycler gradient PCR machine (Eppendorf) using the following thermal profile: $94^{\circ} \mathrm{C}-$ $5 \min , 42^{\circ} \mathrm{C}-5 \min , 72^{\circ} \mathrm{C}-5 \min$ (one cycle); $94^{\circ} \mathrm{C}-1 \mathrm{~min}, 42^{\circ} \mathrm{C}-1$ $\min , 72^{\circ} \mathrm{C}-1 \mathrm{~min}(45$ cycles $)$; final extension at $72^{\circ} \mathrm{C}-10 \mathrm{~min}$.

SCAR primer design and analysis: For developing SCAR markers the desired band was isolated, cloned and sequenced using primers SCOPAE07620F: 5' (AGTGGCAACTCGTCGGTGT) 3' and SCOPAE07620R: 5' (GTGTCAGTGAGAGTAAAGCGTAGGT) 3'). The PCR amplification was carried out in a $25 \mu \mathrm{l}$ reaction mixture containing $8.0 \mathrm{pmol}$ of each primer, $1.5 \mathrm{~mm} \mathrm{MgCl}_{2}$ and $50 \mathrm{ng}$ of genomic DNA while the rest of the PCR components were the same. The thermal cycling conditions were as follows: 1 cycle of $95^{\circ} \mathrm{C}-5$ $\min , 60^{\circ} \mathrm{C}-1 \mathrm{~min}, 72^{\circ} \mathrm{C}-30 \mathrm{~s} ; 35$ cycles of $95^{\circ} \mathrm{C}-1 \mathrm{~min}, 60^{\circ} \mathrm{C}-1$ min and $72^{\circ} \mathrm{C}-30 \mathrm{~s}$ and a final extension at $72^{\circ} \mathrm{C}-10 \mathrm{~min}$.

\section{Results and Discussion}

Identification of RAPD marker for the $S r 26$ gene: A RAPD primer OPAE07 (5' GGAAAGCGTC 3') displayed an amplified DNA fragment of $620 \mathrm{bp}$ designated as OPAE07620 specifically in resistant parent and resistant F2 individuals possibly carrying $\operatorname{Sr} 26$ gene while absent in possibly non-carriers of the Sr26 gene (Figure 1).

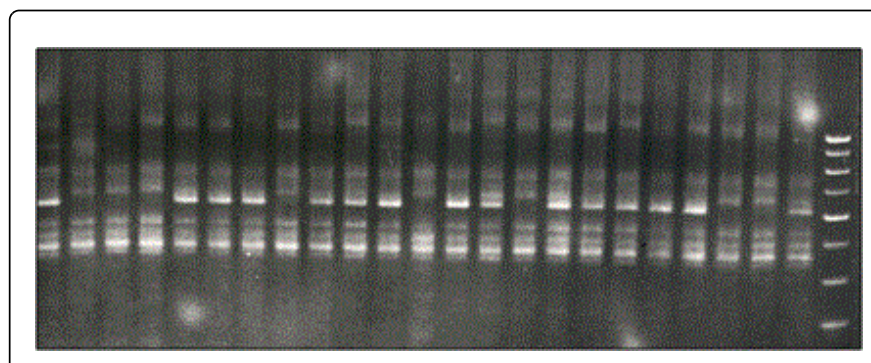

Figure 1: Segregation of RAPD marker OPAE07620 in the F2 population derived from the cross between Kalyan Sona (susceptible) X Kite (resistant carrying Sr26 gene). Lanes marked Ks and $\mathrm{Ki}$ indicate Kalyan Sona and Kite respectively. Lanes marked ' $\mathrm{R}$ ' and ' $S$ ' represents resistant and susceptible individuals. $M=100 \mathrm{bp}$ DNA ladder.

Stem rust inoculation and scoring: Seedlings in field plots, about one month old were inoculated with the pathotype 122 (7G-11, obtained from IIWBR, Regional Station, Flowerdale, Shimla) and disease reactions on the leaves of each plant were recorded at 14 days after inoculation using disease rating scale [22]. To ensure heavy inoculums build-up of stem rust, Cv. Agra Local rows were planted and artificially inoculated with stem rust collected from experimental plots in the previous year. F3 generation rows corresponding to F2 generation plants were also scored for rust resistant phenotype and were characterizing as ( $R R, r r, R r)$ homozygous for resistance or susceptibility, or segregating for resistance to stem rust and also deduce the genotype of respective F2 individuals.

DNA isolation, RAPD and Gel electrophoresis: DNA was extracted from the non-inoculated, fully expanded, 21 days old leaves according

Linkage analysis: A F2 population of 120 plants (Kalyan Sona $x$ Kite) was analysed for segregation of marker and rust resistance phenotypes. In the F2 population, phenotypic ratio of segregation as resistant to susceptible plants and presence of OPAE-07620 to its absence were observed to be 3:1 (Table 2) and showed a good fit to 3:1 ratio $\left(\chi^{2}=0.711\right.$ and $\left.\mathrm{P}=0.80-0.70\right)$. Thus, suggesting monogenic inheritance and dominant action of Sr26 gene. 
Citation: Rai R, Das BK, Bhagwat SG (2017) Development and Validation of Scar Marker for Stem Rust Resistance Gene Sr26 in Wheat (Triticum aestivum L.). Biol Syst Open Access 6: 181. doi:10.4172/2329-6577.1000181

Page 3 of 4

\begin{tabular}{|c|c|c|c|c|c|c|c|}
\hline \multicolumn{5}{|c|}{ F2 genotype } & \multicolumn{3}{|c|}{ Calculated } \\
\hline Crosses & Resistant & Segregating & Susceptible & Total & $x^{2}$ value & Ratio & $P$ value \\
\hline Ks X Kite & $\mathrm{RR}$ & $\mathrm{Rr}$ & $\mathrm{rr}$ & & & & \\
\hline Observed & 33 & 53 & 34 & 120 & 1.576 & $1: 2: 1$ & $0.50-0.30$ \\
\hline Expected & 30 & 60 & 30 & 120 & 1.699 & $3: 1$ & $0.30-0.20$ \\
\hline
\end{tabular}

Table 2: Phenotypic segregation ratio and $\chi^{2}$ test for rust reaction in F2 population derived from the cross Kalyan Sona X Kite.

SCAR marker analysis and validation: SCAR marker (SCOPAE07620) is a dominant marker and showed a tight linkage with the rust resistance phenotype yielded 620 bp band in Kite and resistant F2 plants which was absent in Kalyan Sona and susceptible F2 plants (Figure 2 and Table 2). Based on sequence data of the cloned RAPD marker and using software Primer 3.0, primers were designed and were synthesized by Numex Chemicals, Mumbai, India.

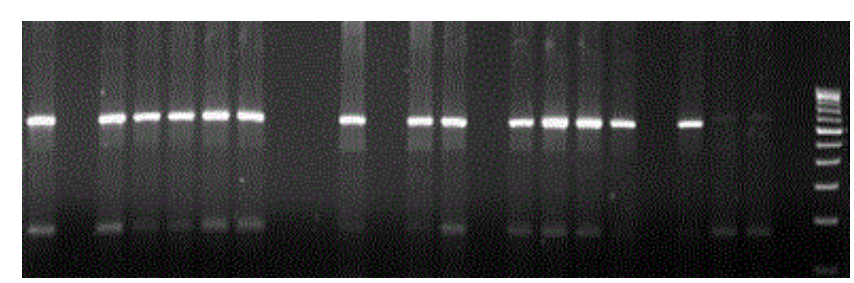

Figure 2: SCAR marker SCOPAE07620 analysis of parents and F2 population of cross between Kalyan Sona and Kite. Lanes marked R and $\mathrm{S}$ indicates resistant and susceptible $\mathrm{F} 2$ individuals respectively. The arrow indicates the position of the SCAR marker. M=100 bp DNA ladder.

Validation of SCAR marker: The SCAR marker SCOPAE07620 was validated using 45 wheat genotypes with known Sr26 status. The SCAR marker was present in all 12 carriers of Sr26 gene while absent in remaining 33 non-carriers of Sr26 gene (Table 1). Validation was also done on other segregating population for Sr26 gene obtained from cross between Kalyan Sona X Takari (resistant: carrying Sr26 gene). The presence or absence of the marker co-segregated with the phenotypic status in the validating population.

\section{Conclusion}

The reported SCAR marker SCOPAE07620 was developed using a cross between Indian cultivar with a carrier of Sr26 gene of Australian origin. Hence this marker will be very valuable in Indian wheat breeding programme and its extensive use can be facilitated by transferring this gene in combination with other genes for enhancement of durability of rust resistance in the wheat lines. During the course of our research, Mago et al. [12] have reported AFLP marker for stem rust resistance gene Sr26 using pair of NILs, however they did not include the co-segregation studies of marker with the phenotypic scoring in an appropriate segregating population. Also linkage analysis of the marker was not done and marker was only associated with the resistance gene. Liu et al. [13] also developed a diagnostic and co-dominant markers for Sr26 using multiplex PCR.
The marker reported in this study is a co-dominant SCAR marker tightly linked $(5.7 \mathrm{~cm})$ to the resistance gene which minimizes the risk of recombination separating the marker from the gene. Marker is polymorphic between gene donor as well as wide range of crop genotypes. Repeatability and reliability of marker was tested and validated on segregating population of appropriate size and hence it is useful for MAS. This study is based on association genetics of the obtained marker with the phenotypic scoring in a F2 segregating population of 120 individuals. The population size is large enough for obtaining linkage between marker and trait of interest. The marker obtained here is $5.7 \mathrm{~cm}$ away, thus it is co-inherited with the disease resistance gene Sr26 which is dependent on the genetic proximity of this marker and the desired gene and can be effectively used in marker assisted selection. The newly identified marker was confirmed by validating it on another segregating population of cross between Kalyan Sona and Takari (carrying Sr26) and wheat genotypes with different Sr26 status. This marker did not amplify in genotypes carrying other stem resistance genes confirming that it can be effectively used in marker assisted selection.

\section{Acknowledgement}

Ruchi Rai thanks CSIR-UGC for providing JRF-SRF fellowship. I would also like to thank Dr. SFD Souza, former Head, NABTD; IARI, New Delhi; IIWBR (DWR), Karnal and NBPGR, New Delhi for supplying the seeds of wheat genotypes and to the IIWBR (DWR) Regional Station, Flowerdale, Shimla for providing the stem rust race 7G-11 and screening for Sr26 in theF3 progenies.

\section{References}

1. Braun HJ, Atlin G, Payne T (2010) Multi-location testing as a tool to identify plant response to global climate change. In Climate change and Crop Production (eds.) Reynolds CRP, CABI, London.

2. Todorovska E, Christov N, Slavov S, Christova P, Vassilev D (2009) Biotic stress resistance in wheat-breeding and genomic selection implications. Biotechnol Biotechnol Equip 23: 1417-1426.

3. Beard C, Jayasena K, Thomas Loughman R (2006) Managing stem rust of wheat. Plant Pathology, Department of Agriculture, Western Australia. Farmnote.

4. Pretorius ZA, Singh RP, Wagoire WW, Payne TS (2000) Detection of virulence to wheat stem rust resistance gene $S r 31$ in Puccinia graminis $\mathrm{f}$. sp. tritici in Uganda. Plant Dis 84: 203.

5. Singh RP, Hodson DP, Huerta-Espino J, Jin Y, Bhavani S, et al. (2011) The emergence of Ug99 races of the stem rust fungus is a threat to world wheat production. Annu Rev Phytopathol 49: 465-481.

6. Knott DR (1961) The inheritance of rust resistance VI. The transfer of stem rust resistance from Agropyron elongatum to common wheat. Can J Plant Sci 41: 109-123. 
Citation: Rai R, Das BK, Bhagwat SG (2017) Development and Validation of Scar Marker for Stem Rust Resistance Gene Sr26 in Wheat (Triticum aestivum L.). Biol Syst Open Access 6: 181. doi:10.4172/2329-6577.1000181

Page 4 of 4

7. Spielmeyer W, Sharp PJ, Lagudah ES (2003) Identification and validation of markers linked to broad spectrum stem rust resistance gene Sr2 in wheat (Triticum aestivum L.). Crop Sci 43: 333-336.

8. Hayden MJ, Kuchel H, Chalmers KJ (2004) Sequence tagged microsatellites for the Xgwm533 locus provide new diagnostic markers to select for the presence of stem rust resistance genes $\mathrm{Sr} 2$ in bread wheat (Triticum aestivum L.). Theor Appl Genet 109: 1641-1647.

9. Olson LE, Guedira GB, Marshall DS, Jin Y, Mergoum M, et al. (2010) Genotyping of U.S. wheat germplasm for presence of stem rust resistance genes Sr24, Sr36 and Sr1RS. Amigo Crop Sci 50: 668-675.

10. Tsilo TJ, Chao S, Jin Y, Anderson JA (2009) Identification and validation of SSR markers linked to the stem rust resistance gene Sr6 on the short arm of chromosome 2D in wheat. Theor Appl Genet 118: 515-524.

11. Tsilo TJ, Jin Y, Anderson JA (2007) Microsatellite markers linked to stem rust resistance allele Sr9a in wheat. Crop Sci 47: 2013-2020

12. Mago R, Bariana HS, Dundas IS, Spielmeyer W, Lawrence GJ, et al. (2005) Development of PCR markers for the selection of wheat stem rust resistance genes $\operatorname{Sr} 24$ and Sr26 in diverse wheat germplasm. Theor Appl Genet 111: 496-504.

13. Liu S, Yu LX, Singh RP, Jin Y, Sorrells ME, et al. (2010) Diagnostic and codominant PCR markers for wheat stem rust resistance genes Sr25 and Sr26. Theor Appl Genet 120: 691-697.

14. Das BK, Saini A, Bhagwat SG, Jawali N (2006) Development of SCAR markers for identification of stem rust resistance gene $S r 31$ in the homozygous or heterozygous condition in bread wheat. Plant Breed 125: 544-549.

15. Zhang W, Olson E, Saintenac C, Rouse M, Abate Z, et al. (2010) Genetic maps of stem rust resistance gene Sr35 in diploid and hexaploid wheat. Crop Sci 50: 2464-2474.
16. Tsilo TJ, Jin Y, Anderson JA (2008) Diagnostic microsatellite markers for the detection of stem rust resistance gene Sr36 in diverse genetic backgrounds of wheat. Crop Sci 48: 253-261.

17. Helguera M, Khan AI, Kolmer J, Lijavetzky D, Zhong-Qi L, et al. (2003) PCR assays for the Lr37-Yr17-Sr38 cluster of rust resistance genes and their use to develop isogenic hard red spring wheat lines. Crop Sci 43:1839-1847.

18. Gold J, Harder D, Smith FT, Aung T, Procunier J (1999) Development of a molecular marker for rust resistance genes Sr39 and Lr35 in wheat breeding lines. Electron J Biotechnol 2: 35-40.

19. Shuangye W, Pumphrey M, Bai G (2009) Molecular mapping of stem-rust resistance gene $S r 40$ in wheat. Crop Sci 49: 1681-1686.

20. Kuchel H, Ye G, Fox R, Jefferies S (2005) Genetic and economic analysis of a targeted marker-assisted wheat breeding strategy. Mol Breed 16: 67-78.

21. Dreher K, Khairallah M, Ribaut JM, Morris M (2003) Money matters (I): Costs of field and laboratory procedures associated with conventional and marker-assisted maize breeding at CIMMYT. Molecular Breeding 11: 221-234.

22. Nayar SK, Tandon JP, Kumar J, Prashar M, Bhardwaj SC, et al. (1994) Basis of rust resistance in Indian wheat. Research Bulletin No. 1, Regional Station, DWR, Flowerdale, Shimla, India

23. Eswaran N, Bhagwat SG, Jawali N (2004) A simple method for isolation of DNA from plants suitable for long-term storage and DNA marker analysis. BARC Newsletter 249: 208-214. 